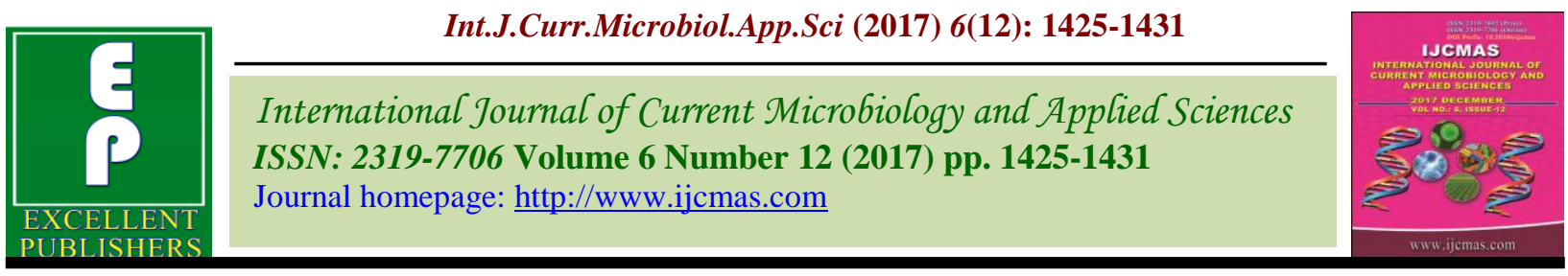

Original Research Article

https://doi.org/10.20546/ijcmas.2017.612.160

\title{
Length-Weight Relationship and Relative Condition Factor of Clarius batrachus (Linnaeus, 1758) from Gaurmati Fish Farm, Kawardha, Chhattisgarh, India
}

\author{
Anirudh Kumar ${ }^{1 *}$, Jitender Kumar Jakhar ${ }^{1}$ and Hemendra Kumar Vardia ${ }^{2}$ \\ ${ }^{1}$ Department of Fish Harvest and Post-harvest Technology, College of Fisheries Kawardha, \\ Chhattisgarh - 491995, India \\ ${ }^{2}$ College of Fisheries Kawardha, Chhattisgarh - 491995, India \\ *Corresponding author
}

A B S T R A C T

\begin{tabular}{|c|}
\hline Keywords \\
\hline $\begin{array}{l}\text { Relative condition } \\
\text { factor, Length-weight } \\
\text { relationship, Clarias } \\
\text { batrachus, Gaurmati. }\end{array}$ \\
\hline Article Info \\
\hline $\begin{array}{l}\text { Accepted: } \\
10 \text { October } 2017 \\
\text { Available Online: } \\
10 \text { December } 2017\end{array}$ \\
\hline
\end{tabular}

Keywords

Relative condition factor, Length-weight relationship, Clarias hus, Gaurmat

\section{Introduction}

The relationship between length and weight of fish having significant importance. If properly applied, this factor is of practical value since it makes possible the conversion of length into weight and vice-versa. Length weight relationship (LWR) is reported for 150 fishes, Clarias batrachus, belonging to family Clariidae. Clarias batrachus, now called Clarias magur, is an air-breathing endangered catfish (Vishwanath, 2010). This fish have great demand and attracts the attention of farmers for its high market value in Bangladesh (Hossain et al., 2006). The relationship between length and weight in fish is affected by number of factors including seasons, habit, gonad, maturity, sex, diet, stomach fullness, health, preservation techniques and locality (Tesch, 1971). This relationship has several applications, mostly in fish stock assessment (Richter, et al., 2000). For estimation of weight-at-age (Petrakis and Stergiou, 1995) and the conservation of growth-in length is equivalent to the growth-in-weight (Pauly, 1993). The establishment of length-weight relationship (LWR) is often needed for the calculation of production and biomass of a fish population (Anderson, et al., 1983), based on visual 
census (Santos, 1997). Finally, LWR allow life history and morphological comparisons between different fish species or between fish populations from different habitats and/or regions (Goncalves et al., 1997). The LWR is an important tool in fish biology, physiology, ecology and fisheries assessment (Oscoz et al., 2005). Among several applications of LWR in fish biology, knowledge of these relationships is useful for the production of weight from length values as an indication of fish condition or for fish stock assessment (Petrakis and Stergiou, 1995), (Froese and Pauly, 2006). A length-weight relationship (LWR) has both basic and applied applications in fishery management practices (Pitcher and Hart, 1982), (Kar and Barbhuiya, 2010). It explores the basis for estimation of length from weight observations or reverse calculations.

It also helps to calculate biomass production of a fish population and information on natural stocks and/or organism condition. Length-length relationships (LLRs) are also useful in fisheries management for overall growth studies (Jhingran, 1952), (Fafioye and Oluajo, 2005). The condition of a fish exhibits the recent biological and physical circumstances, and varies due to changed feeding conditions, pathogen infestations, body physiology and other ecological factors (Le Cren, 1951; Miranda, et al., 2006). Thus, the main aim of the present study is to find out length - weight relationship and relative condition factors for Asian catfish, Clarias batrachus.

\section{Materials and Methods}

The samples of Asian catfish, Clarias batrachus were collected from Gaurmati fish farm, Kawardha, Chhattisgarh with the help of drag net. Fisheries management and research often require the use of biometric relationships in order to transform data collected in the field into appropriate index (Anderson, et al., 1983), (Chowdhury, 1981). The specimens were preserved in $4 \%$ buffered alcohol-formalin, packed in bottles and transported to the laboratory. All specimens (150 no.) were measured for total length (TL) by using centimeter measuring scale to the nearest $1.0 \mathrm{~cm}$ level and total weight with the help of digital balance to the nearest $1.0 \mathrm{~g}$ and get categorized into 4 category viz. $10-15 \mathrm{~cm}$ (L1), 16 - $20 \mathrm{~cm}$ (L2), $21-25 \mathrm{~cm}$ (L3) and 26 - $30 \mathrm{~cm}$ (L4). All length - weight relationships were calculated using the least square fitted method to log transformed data using the function $\mathrm{W}=\mathrm{ax} \mathrm{L}^{\mathrm{b}}$

Where,

$\mathrm{W}=$ Total weight of the fish in grams

$\mathrm{L}=$ Total length in $\mathrm{cm}$

$\mathrm{a}=$ coefficient related to body form

$\mathrm{b}=$ an exponent indicating isometric growth.

The parameters "a" and "b" was estimated by linear regression on transformed equation:

$\log W=\log a+b \log L($ LeCren, 1951)

The Ponderal index $(\mathrm{Kn})$ or relative condition factor value was calculated for different length groups of $10 \mathrm{~cm}$ interval. The formula $\mathrm{Kn}=\mathrm{W} / \mathrm{aL}^{\mathrm{n}}$ (LeCren, 1951) were used for calculation of relative condition factor.

\section{Results and Discussion}

\section{Length- weight relationship}

The length-weight relationship for Clarius batrachus get determined by equation suggested by (LeCren, 1951) Log W = Log a $+b \log$ L. When empirical values of lengths were plotted against their respective weight on an arithmetic scale, smooth curves were obtained (Fig. 1). The relationship between observed and calculated weight also get 
presented (Fig. 2). The data of length-weight of Clarius batrachus is presented in (Table 1). The regression coefficients, when calculated using least square method for Clarius batrachus whose size ranged between 10 and $28 \mathrm{~cm}$ gave the following equation:

$\log \mathrm{W}=-2.34+3.19 \log \mathrm{L}$.

As observed from the above equation values for all specimens were practically identical and followed the cube law $(b=3)$. The agreement between the empirical weight and computed weight from regression can be termed as ideal growth (positive allometry). The minimum calculated weight were found for length group $10-15 \mathrm{~cm}$ i.e. 12.43 gram having observed weight 15.98 gram and maximum calculated weight were found for length group $26-30 \mathrm{~cm}$ i.e. 161.32 gram having observed weight 175.00 gram.

\section{Relative condition factor}

The relative condition factor $(\mathrm{Kn})$ for all fish samples was determined from the average lengths and weights of $05 \mathrm{~cm}$ interval of total length groups (Table 2). The relative condition factor $(\mathrm{Kn})$ was determined for all samples in case of sexes combined only $\mathrm{Kn}$ values were ranging from $1.03-1.08$ with mean was $1.005 \pm 0.003$. The $\mathrm{Kn}$ value increases with length and this value of $\mathrm{Kn}$ showed ideal or good growth of all samples in all size groups of fish. In case of month wise, the minimum relative condition factor found was 1.00 in the month of January, February, March and April. The maximum relative condition factor found is 1.05 in the month of September followed by 1.04 in the month of August and October, 1.03 in July, 1.02 in may and November and 1.0 in rest of the months (Table 3 and Fig. 3).

Table.1 Data on length and weight of Clarius batrachus from Gaurmati fish farm, kawardha, Chhattisgarh

\begin{tabular}{|l|l|l|}
\hline Length groups & Mean length $(\mathbf{c m})$ & Mean Weight $(\mathbf{g})$ \\
\hline L1 & $13.02 \pm 0.23$ & $15.98 \pm 0.55$ \\
\hline L2 & $17.88 \pm 0.21$ & $50.09 \pm 3.00$ \\
\hline L3 & $23.44 \pm 0.16$ & $115.26 \pm 3.76$ \\
\hline L4 & $26.66 \pm 0.66$ & $175.00 \pm 5.13$ \\
\hline
\end{tabular}

Table.2 Relative condition factor (Kn) values of Clarius batrachus from Gaurmati fish farm, kawardha, Chhattisgarh

\begin{tabular}{|c|c|c|c|}
\hline $\begin{array}{c}\text { Length group } \\
(\mathbf{c m})\end{array}$ & $\begin{array}{c}\text { Observed weight } \\
(\mathrm{W})\end{array}$ & $\begin{array}{c}\text { Calculated weight } \\
\left(a^{\mathbf{b}}\right)\end{array}$ & $\begin{array}{c}\text { Relative condition factor } \\
\mathrm{Kn}\left(\mathrm{W} / \mathbf{a L}^{\mathrm{b}}\right)\end{array}$ \\
\hline L1 & 15.98 & 12.43 & 1.03 \\
\hline L2 & 50.09 & 47.57 & 1.05 \\
\hline L3 & 115.26 & 108.02 & 1.06 \\
\hline $\mathrm{L} 4$ & 175.00 & 161.32 & 1.08 \\
\hline \multicolumn{4}{|c|}{ Mean Kn $=1.005 \pm 0.003$} \\
\hline
\end{tabular}


Table.3 Month wise Relative condition factor $(\mathrm{Kn})$ values for combined sexes of Clarius batrachus from Gaurmati fish farm, kawardha, Chhattisgarh

\begin{tabular}{|l|c|c|c|}
\hline \multicolumn{1}{|c|}{ Month } & $\begin{array}{c}\text { Observed weight } \\
(\mathbf{W})\end{array}$ & $\begin{array}{c}\text { Calculated weight } \\
\left.\mathbf{( a \mathbf { ~ }}^{\mathbf{b}}\right)\end{array}$ & $\begin{array}{c}\text { Relative condition factor, } \\
\mathbf{K n}\left(\mathbf{W} / \mathbf{a}^{\mathbf{b}}\right)\end{array}$ \\
\hline January & 13.82 & 13.70 & 1.00 \\
\hline February & 13.97 & 13.94 & 1.00 \\
\hline March & 18.38 & 18.28 & 1.00 \\
\hline April & 19.75 & 19.57 & 1.00 \\
\hline May & 33.20 & 32.48 & 1.02 \\
\hline June & 19.95 & 19.59 & 1.03 \\
\hline July & 69.08 & 66.68 & 1.04 \\
\hline August & 120.73 & 115.65 & 1.05 \\
\hline September & 170.71 & 161.61 & 1.04 \\
\hline October & 164.33 & 157.40 & 1.02 \\
\hline November & 164.09 & 160.55 & Mean Kn $=\mathbf{1 . 0 1 9} \pm 0.005$ \\
\hline December & 66.30 & 65.46 & \multicolumn{2}{|c|}{} \\
\hline \multicolumn{2}{|l|}{}
\end{tabular}

Fig.1 Length - weight relationship of Clarius batrachus from Gaurmati fish farm, kawardha, Chhattisgarh

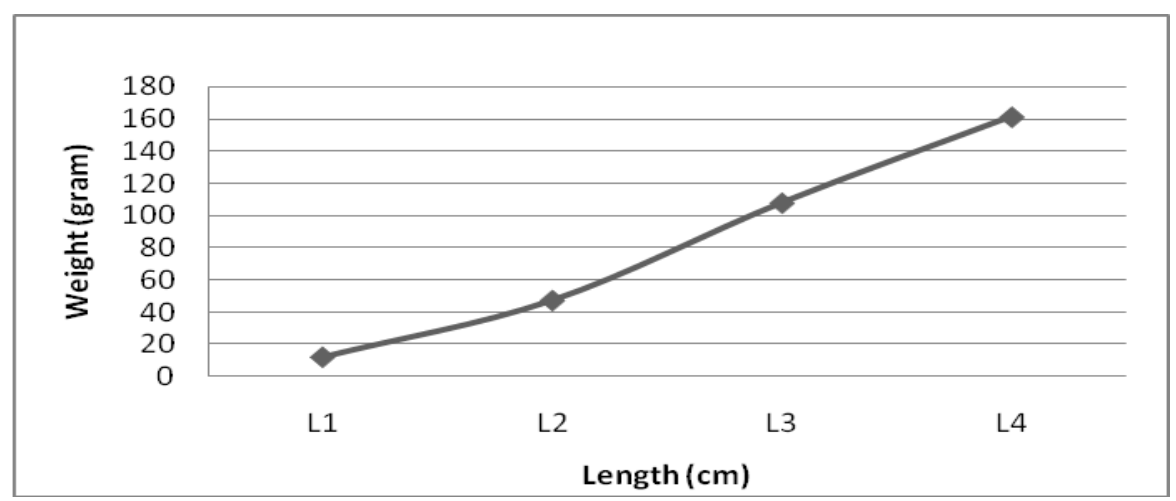

Fig.2 Observed and calculated weight in different mean length groups of Clarius batrachus from Gaurmati fish farm, kawardha, Chhattisgarh

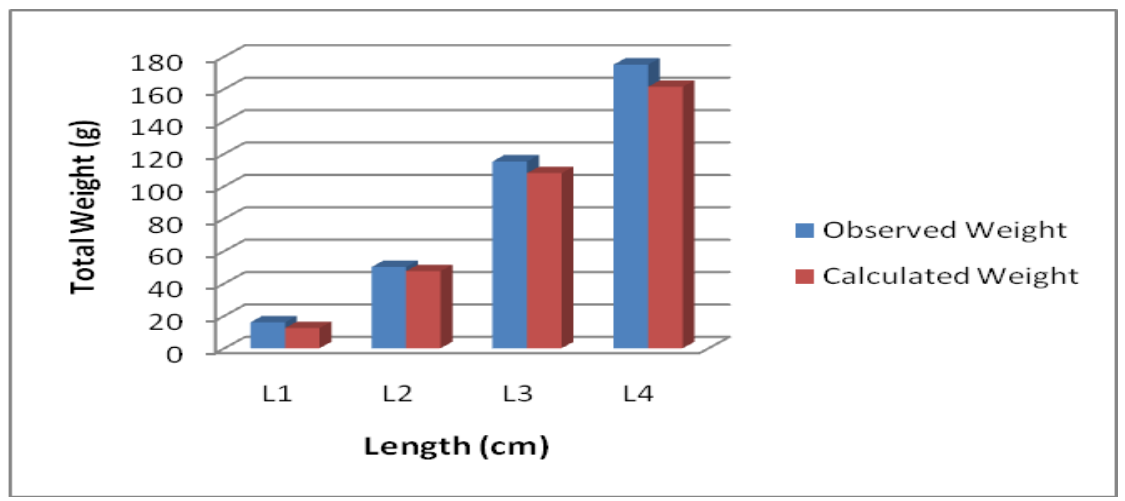


Fig.3 Month wise relative condition factor of Clarius batrachus from Gaurmati fish farm, kawardha, Chhattisgarh

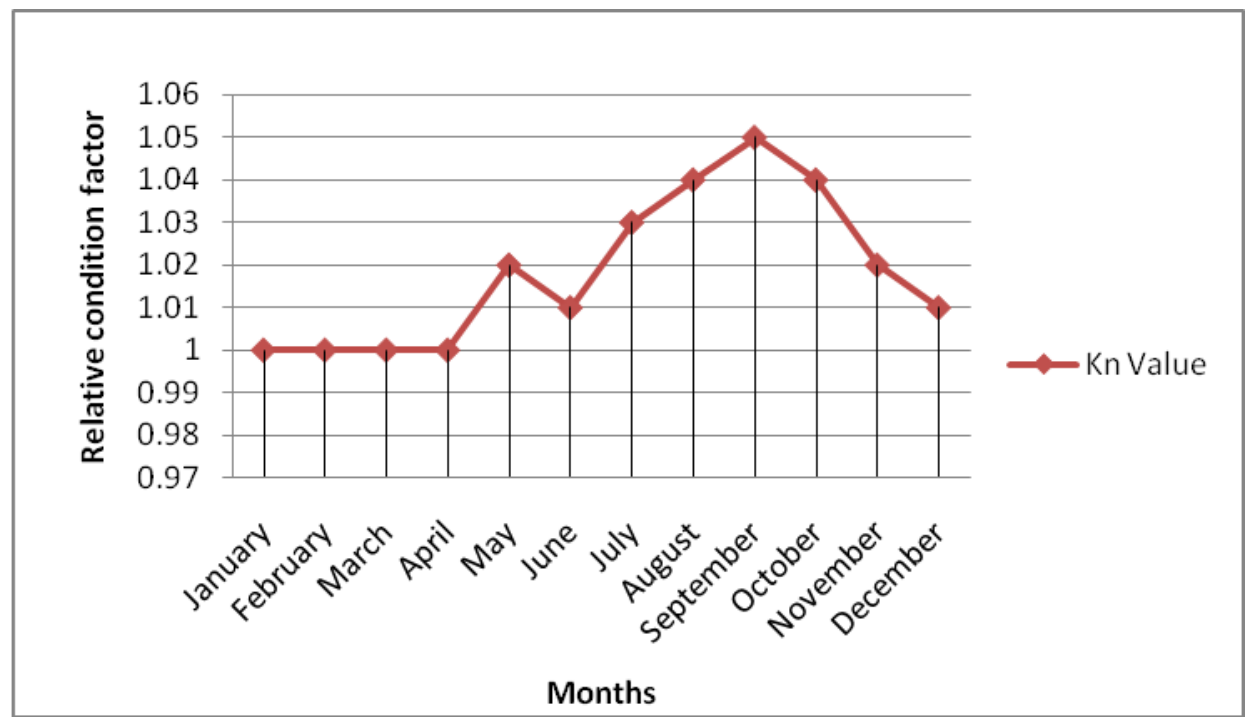

The differences in weight as observed in this study could be due to individual condition factor which is the wellbeing and degree of fatness of an animal (Pauly, 1983). It could be linked with season as the highest weight of fish was recorded in September which is the post monsoon season. The " $b$ " values of this study revealed that the $C$. batrachus of Gaurmati fish farm exhibited positive allometric growth. According to (Khairenizam and Norma-Rashid, 2002), when the " $b$ " value is less than 3 , the fish has a negative allometric growth but when it is greater than 3 , it has a positive allometric growth and when it is equal to 3 , the fish has isometric growth. The values of "b" obtained in this study are supported by studies by (Chaudhary and Srivastava, 2013) that reported "b" value of 3.48 for combined sexes of cultured C. batrachus. Clarias batrachus in the present study had regression equation for the combined sexes which was similar to that of (Srisuwantach et al.,1980) of $\log \mathrm{W}=-$ $2.1692+3.0857 \log \mathrm{L}$ for cultured $C$. batrachus. Pepple and Ofor (2011) obtained a positive allometric growth with regression equation for the combined sexes as Log $\mathrm{W}=$ $2.1612+3.0445 \log \mathrm{L}$ for Heterobranchus longifilis reared in earthen ponds in Lagos State. According to (Bagenal and Tesch, 1978), (Koutrakis and Tsikliras, 2003), allometric coefficients "b" may range from 24. From length - weight parameters $(a, b)$, fishes are affected by a series of factors such as season, habitat, gonad maturity, sex, diet, stomach fullness, health, preservation techniques and annual differences in environmental conditions (Bagenal and Tesch, 1978; Froese, 2006). Such differences in "b" values can be described to one or a combination of factors including differences in the number of specimens examined, area and season effects and distinctions in the observed length ranges of the specimens caught, to which duration of sample collection can be added as well (Moutopoulos and Stregiou, 2002). The relative condition factors were similar to the values (1.04) documented by (Chaudhary and Srivastava, 2013) for $C$. batrachus under poor availability in natural conditions from Unnao, Uttar Pradesh. According to (Deekae et al., 2010) several factors affect the relative condition factor of fishes. They range from feeding, spawning, food nutrient composition and fat accumulation. The variations of relative 
condition factor $(\mathrm{Kn})$ in fish according to (King, 1995) may be due to food abundance, adaptation to the environment and gonadal development. The overall mean relative condition factor obtained in this study is slightly higher than the result obtained by (Asha, et al., 1993) for C. batrachus in freshwater Fish Farm, Balabhadrapuram, Andhra Pradesh.

\section{References}

Anderson, R., Gutreuter, S., 1983. L. Nielsen and D. Johnson (Eds). American Fisheries Society, Bethesda, MD, USA, pp. 283-300.

Asha, T., Landge, K., Venka'i'eshvaran, G., and Venugopal, 1993. Field trials on culture of Clarias batrachus, freshwater fish farm, balabhadrapuram, Andhra Pradesh. journal of the Indian fisheries association. 23, 15-20

Bagenal, T.B., and Tesch, F.W., 1978. Age and growth, In: Bagenal, T. (Ed). Methods of Assessment of fish production in fresh water, Oxford Blackwell Scientific Publication, pp.101-136.

Chaudhary, S. and Srivastava, P.P., 2013. Length-weight relationships (LWR) of threatened Asian catfish, Clarias batrachus under poor availability in natural conditions from Unnao, Uttar Pradesh, India. Advances in Applied Science Research, 2013, 4(6): 138-14

Chowdhury, M. F. 1981. A study on the chemical composition and nutritive quality of some freshwater zeol fishes of Bangladesh. M.Sc. Thesis, Faculty of Fisheries, Bangladesh Agricultural University, Mymensingh.

Deekae, S.N., Chukwu, K.O., and Awotogha, G., 2010. Length -Weight relationship and condition factor of Alestis alexandrius (Geoffrey Saint Hillarie
1817) in Bonny River, Nigeria. Journal of Agricultural Research and Policies, 5(4): 1618.

Fafioye, O.O., and Oluajo, O.A., 2005. Length-weight relationships of five fish species in Epe lagoon, Nigeria. Afr. J. Biotechnol. 4: 749-751.

Froese, R., and Pauly, D., (Eds) 2006. FishBase 2006. World Wide Web electronic publication. http://www. fishbase.org.

Goncalves, J. M. S., Bentes, L., Lino, P. G., Ribeiro, J., Cana' rio, A. V. M., and Erzini, K., 1997. Weight-length relationships for selected fish species of the small-scale demersal fisheries of the south and south-west coast of Portugal, Fish Res. 30, 253-256.

Hossain, M.Y., Ahmed, Z.F., Leunda, P.M., Jasmine, S., Oscoz, J., Miranda, R. and Ohtom,i J., 2006. J. Appl. Ichthyol. 22: 304-307.

Jhingran, V. G., 1952. General length weight relationship of three major carps of India. Proceedings of National Institute of Science India, 18, 449-460.

Kar, D., and Barbhuiya, M.H., 2010. Length weight relationship and condition factor in Puntius amphibious (Valenciennes) and Puntius vittatus (Day) from Barak Valley region of Assam. J. of Inland Fish. Soc. 42 (1) : 76-77.

Khaironizam, M.Z., and Norma-Rashid, Y., 2002. Length-weight relationship of mudskippers (Gobiidae: Oxudercinae) in the coastal areas of Selangor, Malaysia. NAGA-World Fish Centre Q., 25: 20-22.

King, M., 1995. Fisheries biology, assessment and management, Fishing News Books, Oxford, England.

Koutrakis, E.T., and Isikliras, A.C., 2003. Length-Weight relationship of fishes from three Northern Aegean Estuarine 
Systems (Greece), Journal of Applied Icthyology, 19: 258-260.

LeCren, E. D., 1951. The length-weight relationship and seasonal cycle in gonad weight and condition in the perch (Perca fluviatilis). Animal Ecology, 20, 201-219. Retrieved from http://www.jstor.org/stable/1540.

Miranda, R., Oscoz, J., Leunda, P.M., and Escala, M.C., 2006. Weight-length relationships of cyprinid fishes of the Iberian Peninsula. J. Appl. Ichthyol. 22: 297-298.

Moutopoulos, D.K., and Stregiou, K.I., 2002. Length Weight and Length-Length relationships of fish species from the Aegean Sea (Greece), Journal of Applied Ichthyology, 18: 200-203.

Oscoz, J., Campos, F., Escala, M. C., 2005. Weight-length relationships of some fish species of the Iberian Peninsula. $J$. Appl. Ichthyol. 21, 73-74.

Pauly, D., 1993. Fishbyte section editorial. Naga ICLARM, Q. 16, 26.

Pepple, P.C.G., Ofor, C.O., 2011. Length Weight relationship of Heleterobranchus longifilis reared in earthen Ponds, Nigerian Journal of Fisheries, 8(2): 315-321.
Petrakis, G., and Stergiou, K. I., 1995. Weight-length relationships for 33 species in Greek waters. Fish. Res., 21: 465-469.

Pitcher, T.J., and Hart, P.J., 1982. Fisheries Ecology. Chapman and Hall, London.

Richter, H., Lu"cksta"dt, C., Focken, U., Becker, K., 2000. Arch. Fish. Mar. Res. 48, 255-264.

Santos, M. N., 1997. PhD Thesis, Universidade do Algarve, Faro, pp. 268.

Srissuwantach, V., Soungchomphan, R., and Sae-Eng, P., 1980. Water quality conditions as disease related stressors in Clarias ponds, Ecology Technical Paper No. 3, Ecology Unit, National Inland Fisheries Institute, Bangkok, Thailand, 33p.

Tesch, F.W., 1971. Age and growth. In: Methods for assessment of fish production in fresh waters. W. E. Ricker (Ed.). Blackwell Scientific Publications, Oxford, pp. 99-130.

Vishwanath, W., 2010. Clarias magur. In: IUCN 2013. IUCN Red List of Threatened Species. Version 2013.1.

\section{How to cite this article:}

Anirudh Kumar, Jitender Kumar Jakhar and Hemendra Kumar Vardia. 2017. Length-Weight Relationship and Relative Condition Factor of Clarius batrachus (Linnaeus, 1758) from Gaurmati Fish Farm, Kawardha, Chhattisgarh. Int.J.Curr.Microbiol.App.Sci. 6(12): 1425-1431. doi: https://doi.org/10.20546/ijcmas.2017.612.160 